\title{
PENYULUHAN DAN VAKSINASI AYAM BURAS DI DESA NYAMBU KECAMATAN KEDIRI KABUPATEN TABANAN
}

\author{
G.A.Y Kencana ${ }^{1}$, IN.Suartha ${ }^{2}$ I.A.P.Apsari ${ }^{3}$, Anak Agung Sagung Kendran ${ }^{4}$, Ida Bagus Kade \\ Suardana ${ }^{5}$
}

\begin{abstract}
ABSTRAK
Hospes utama penyakit Flu Burung adalah unggas termasuk ayam buras yang berpotensi tinggi sebagai penular dan penyebar penyakit karena sistim pemeliharannya secara semi intensif. Kasus kematian manusia akibat Flu Burung pernah terjadi di Banjar Batugaing Desa Beraban Kecamatan Kediri. Desa Nyambu terletak di Kecamatan Kediri, Kabupaten Tabanan. Populasi ayam buras di Kecamatan Kediri sebanyak 30.171 ekor pada tahun 2016. Mengingat potensi Desa Nyambu dengan penduduk yang kebanyakan memelihara ayam buras secara semi intensif, maka sangat rentan terjadinya penyebaran penyakit Flu Burung di Desa tersebut. Tujuan pengabdian masyarakat di Desa Nyambu adalah untuk mencegah timbulnya penyakit Flu Burung yang ditularkan oleh unggas. Sasaran utama adalah masyarakat yang memelihara ayam buras. Kegiatan pengabdian masyarakat diawali dengan penyuluhan yang dilakukan pada tanggal 28 Juli 2018 di Kantor Desa Nyambu. Peserta penyuluhan adalah aparat Desa beserta masyarakat setempat. Materi penyuluhan meliputi pengenalan gejala klinis penyakit Flu Burung dan cara mencegah dengan vaksinasi. Vaksinasi pada ayam buras dilakukan dari satu rumah ke rumah lainnya (door to door) dengan menggunakan vaksin AI inaktif melalui suntikan intramuskuler pada paha. Sebanyak 230 ayam buras berbagai umur telah berhasil divaksinasi.
\end{abstract}

Kata kunci: penyuluhan, vaksinasi, Flu Burung, ayam buras, Tabanan.

\begin{abstract}
The main host of Avian Influenza is poultry, including domestic chickens because domestic chickens are kept without cages (released). Extraordinary Avian Influenza has occurred in Indonesia, including in Tabanan Regency, Bali in 2003-2006. The case of human deaths due to Bird Flu had occurred in Banjar Batugaing Desa Beraban in Kediri District. Nyambu Village is located in Kediri Subdistrict, Tabanan Regency, many residents raise domestic poultry. The total population of free-range chickens in Kediri District is 30,171 in 2016. Considering the potential of Nyambu Village whose residents mostly raise free-range chicken by means of release, it is very vulnerable to the spread of Avian Influenza in the Village. The purpose of community service in Nyambu Village is to prevent the onset of Avian Influenza. The main target of community service in Nyambu Village is the villagers who maintain free-range chicken. Community service activities

\footnotetext{
1 Labolatorium Virologi, Fakultas Kedokteran Hewan, Universitas Udayana, Jl. P.B. Sudirman, Denpasar yuniatikencana@unud.ac.id

${ }^{2}$ Labolatorium Ilmu Penyakit Dalam, Fakultas Kedokteran Hewan, Universitas Udayana, Jl. P.B. Sudirman, Denpasar

${ }^{3}$ Labolatorium Parasitologi, Fakultas Kedokteran Hewan, Universitas Udayana, Jl. P.B. Sudirman, Denpasar

${ }^{4}$ Labolatorium Patologi Klinik, Fakultas Kedokteran Hewan, Universitas Udayana, Jl. P.B. Sudirman, Denpasar

${ }^{5}$ Labolatorium Virologi, Fakultas Kedokteran Hewan, Universitas Udayana, Jl. P.B. Sudirman, Denpasar
} 


\section{G.A.Y Kencana, IN.Suartha, I.A.P.Apsari, Anak Agung Sagung Kendran, Ida Bagus Kade Suardana}

have been carried out on July 28, 2018 at the Nyambu Village Office followed by the Village apparatus and the local community. They were given counseling then continued with vaccination on their domesticated chickens from one house to another, it's used AI inactive vaccine by intramuscullare injected. As many as 230 domestic chickens of various ages have been successfully vaccinated

Keywords: Counseling, vaccination, Avian Influenza, domestic chickens,Tabanan

\section{PENDAHULUAN}

Penyakit Avian Influenza (AI) bersifat zoonosis yakni dapat menyerang hewan maupun manusia dan bersifat fatal karena dapat mengakibatkan kematian baik pada unggas maupun pada manusia yang terserang. Agen penyebabnya dalah virus familia Orthomyxoviridae) genus Avian Influenza subtipe H5N1 (Jong and Hien., 2006). Wabah penyakit AI yang sangat merugikan dan menimbulkan korban tinggi pada manusia sudah pernah dilaporkan di Indonesia ((Daniels et al., 2013). Di Indonesia penyakit AI dikenal juga dengan nama penyakit Flu Burung. Penularan penyakit Flu Burung terjadi secara kontak langsung dengan unggas sakit maupun penularan secara tidak langsung melalui cemaran. Hospes utama penyakit Flu Burung adalah unggas termasuk diantaranya ayam buras yang berpotensi tinggi sebagai penular dan penyebar penyakit Flu Burung. Hal ini terjadi karena cara pemeliharaan ayam buras di pedesaan pada umumnya tanpa dikandangkan atau dilepaskan di pekarangan atau bebas berkeliaran seperti dimuat pada Gambar 1.

Hasil survey penyakit Flu Burung di Kabupaten Tabananan pada tahun 2005-2006 dilaporkan bahwa virus AI ganas atau Highly Pathogenic Avian Influenza subtipe H5N1 telah berhasil diisolasi dari ayam buras dari peternakan rakyat (backyard animals), beberapa diantaranya juga bahkan juga ditemukan pada anjing dan kucing (Mahardika et al., 2005; Mahardika et al., 2006; Mahardika et al., 2017). Kejadian Luar Biasa penyakit Flu Burung pernah terjadi di Indonesia termasuk juga di Kabupaten Tabanan, Bali pada tahun 2003-2006. Kasus kematian manusia akibat Flu Burung dilaporkan di Banjar Batugaing Desa Beraban Di Kecamatan Kediri, Tabanan.

Desa Nyambu juga merupakan bagian dari Kecamatan Kediri Kabupaten Tabanan. Penduduk Desa Nyambu banyak memelihara ayam buras. Jumlah populasi ayam buras di Kecamatan Kediri sebanyak 30.171 ekor pada tahun 2016 (BPPS Tabanan, 2017). Hampir setiap hari terjadi tranportasi unggas yang melewati Desa Nyambu menuju Denpasar baik ke Pasar Beringkit, maupun ke Pasar Badung dan sekitarnya.

Pencegahan penyakit Flu Burung pada unggas dengan cara divaksinasi menggunakan vaksin AI inaktif sediaan tunggal maupun dikombinasi dengan vaksin lain (Kencana et al., 2015). Vaksin AI 
ada yang dikombinasi dengan vaksin Newcastle Disease (ND) karena kedua penyakit tersebut pada unggas mempunyai gejala klinis yang mirip yakni demam, diare, gangguan syaraf, penurunan produksi telur diikuti dengan angka sakit dan kematian yang tinggi dalam waktu yang singkat. Pencegahan penyakit dengan cara diberikan vaksin kombinasi ND-AI pada ayam bertujuan untuk mencegah dua penyakit virus tersebut dalam waktu yang bersamaan. Hasil penelitian pemberian vaksin kombinasi ND-AI pada ayam petelur ternyata aman dan tidak menyebabkan sakit tetapi justru mampu meningkatkan titer antibodi protektif yang mulai muncul sejak dua minggu pasca divaksinasi (Kencana et al., 2016).

Mengingat sebagian besar penduduk Desa Nyambu memelihara ayam buras dengan cara dilepaskan dan bebas berkeliaran maka hal ini sangat rentan terinfeksi oleh virus Flu Burung. Selain itu, ayam yang telah sakit akan dengan mudah menularkan penyakitnya ke ayam lain disekitarnya dan berpotesi sebagai penyebar penyakit AI di Desa Nyambu. Oleh karena itu penyuluhan dan vaksinasi AI pada ayam buras sangat perlu dilakukan. Setelah diberikan penyuluhan maka diharapkan prilaku penduduk Desa Nyambu dalam memelihara ayam buras akan merubah. Mereka diharapkan dapat melakukan vaksinasi dan menjaga kesehatan ayam serta lingkungannnya guna mencegah munculnya penyakit Flu Burung di Desa Nyambu.

\section{METODE PEMECAHAN MASALAH}

\section{Penyuluhan}

Penyuluhan Flu Burung dilakukan di Bale Banjar Desa Nyambu. Kegiatan ini dihadiri oleh Aparat Desa beserta masyarakat setempat. Materi penyuluhan meliputi bahaya penyakit Flu Burung, cara penularan Flu Burung, gejala klinis dan perubahan patologi anatomi ayam yang terinfeksi Flu Burung. Dijelaskan pula dalam materi penyuluhan tentang biosekuriti dan pentingnya melakukan pencegahan Flu Burung melalui vaksinasi.

\section{Vaksinasi Ayam Buras}

Pelayanan yang diberikan kepada masyarakat meliputi vaksinasi pada ayam buras dengan menggunakan vaksin inaktif Flu Burung Sanavac. Vaksinasi dilakukan secara door to door dengan mendatangani rumah-rumah penduduk yang memelihara ayam buras. Pada kesempatan tersebut masyarakat diajari cara melakukan vaksinasi AI pada ayam buras dengan menyuntikkan satu dosis vaksin AI inaktif secara intramuskuler. Ayam direstrain pada posisi dorsolateral, lalu daerah tempat dilakukan vaksinasi pada ayam terlebih dahulu didesinfeksi dengan alkohol 70\%, ditunggu 


\section{G.A.Y Kencana, IN.Suartha, I.A.P.Apsari, Anak Agung Sagung Kendran, Ida Bagus Kade Suardana}

sebentar agar alkoholnya menguap. Diambil vaksin sebanyak satu dosis dengan menggunakan tuberculin syringe lalu diinjeksikan pada otot paha atau otot dada.

\section{HASIL DAN PEMBAHASAN}

Kegiatan pengabdian masyarakat sudah dilakukan pada tanggal 28 Juli 2018, di Desa Nyambu Kecamatan Kediri-Tabanan. Penyuluhan yang diberikan meliputi: bahaya penyakit Flu Burung yang bersifat zoonosis (dapat menulari manusia) dan menyebabkan kematian baik pada unggas maupun manusia yang terinfeksi (Dudley., 2008). Dijelaskan pula dalam penyuluhan tersebut tentang cara penularan penyakit Flu Burung, gejala klinis dan tanda-tanda yang menciri dari penyakit Flu Burung serta perubahan patologinya. Materi penyuluhan juga disampaikan cara pencegahan penyakit Flu Burung dan tindakan biosekuriti. Pada saat penyuluhan diselingi dengan diskusi yang mendapat tanggapan sangat bagus dari peserta. Masyarakat sangat antusias mengikuti jalannya penyuluhan dan diskusi disela-sela kegiatan presentasi. Aktivitas diskusi dengan peserta dimuat pada Gambar 1, 2, dan 3

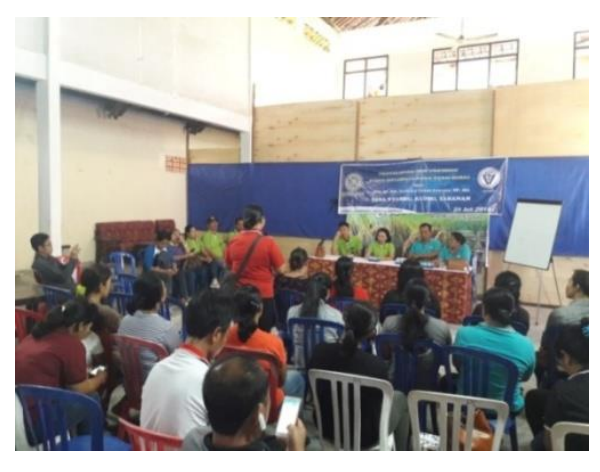

Gambar 1. Penyuluhan AI di Desa Nyambu

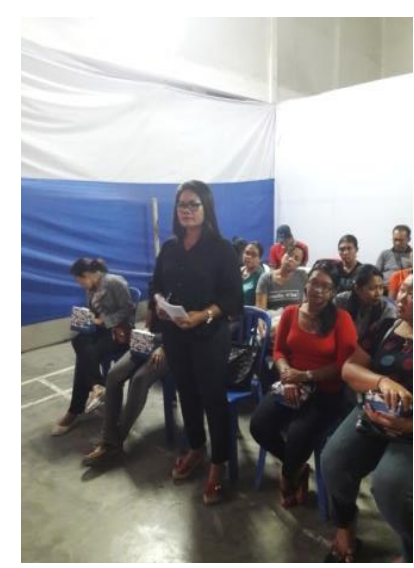

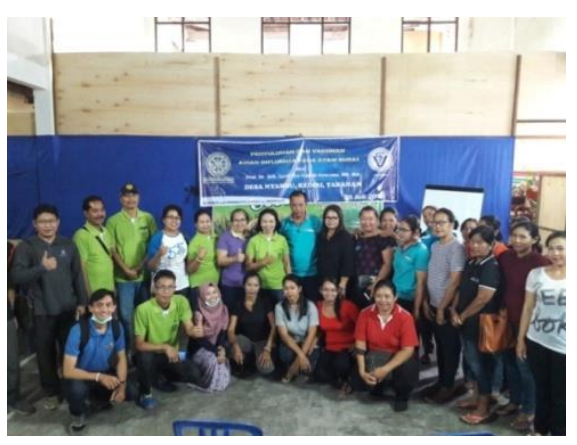

Gambar 2.Peserta Penyuluhan AI

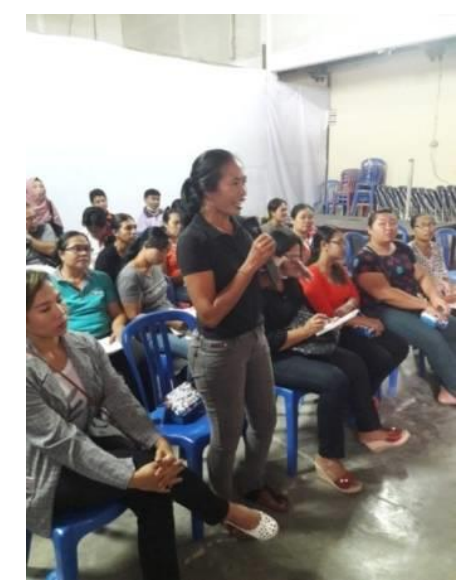


Vaksinasi Flu Burung pada ayam buras yang dilakukan secara door to door ke rumah-rumah penduduk yang memiliki ayam buras disambut baik oleh masyarakat setempat. Hasil survey lapangan diperoleh informasi bahwa kurang lebih satu bulan sebelumnya beberapa ayam mati secara mendadak di Desa tersebut. Masyarakat menyebutkan ayam peliharaannya terkena gerubug sehingga populasi ayam buras di desa Nyambu menurun. Saat dilakukan vaksinasi juga diberikan penjelasan kepada peternak yang tidak hadir pada saat penyuluhan, tentang bahaya penyakit Flu Burung dan cara pencegahan dengan vaksinasi. Sebanyak 230 ekor ayam berbagai umur telah berhasil divaksinasi. Beberapa dokumentasi kegiatan vaksinasi pada ayam buras di Desa Nyambu dimuat pada Gambar 5, 6 dan 7.

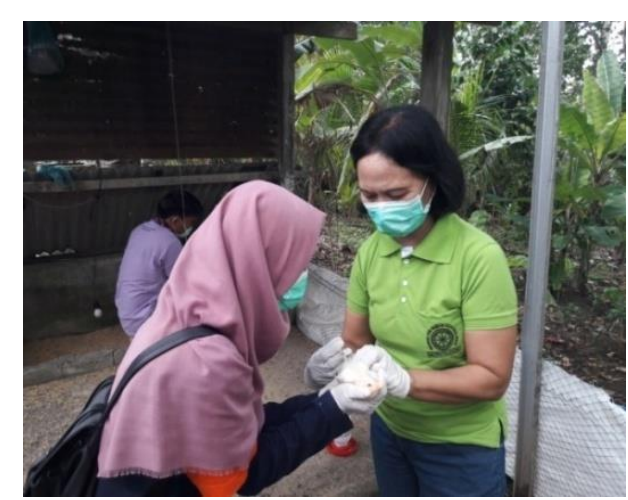

Gambar 5

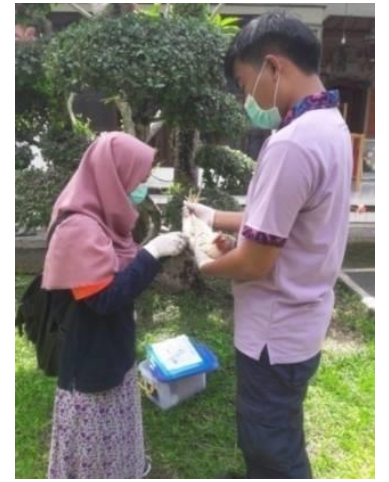

Gambar 6

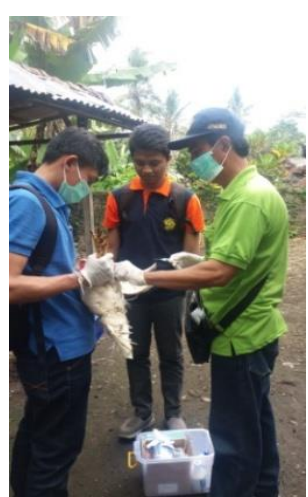

Gambar 7

Gambar 5,6 dan 7. Vaksinasi pada ayam buras di Desa Nyambu, Kediri

Penyuluhan dan vaksinasi Flu burung pada ayam buras sangat penting untuk dilakukan. Hasil riset menunjukkan bahwa virus AI-H5N1 ternyata ditemukan bersirkulasi pada ayam buras di Tabanan (Kencana et al., 2018). Hal ini perlu diwaspadai mengingat ayam buras tidak divaksinasi dan dipelihara secara semi intensif (siang dilepaskan, malam dikandangkan). Keadaan ini memicu terjadinya penyebaran penyakit Flu burung karena ayam buras dapat tertular virus AI dan mampu menyebarkan virus ke sekitarnya. Monitoring virus Flu Burng mesti dilakukan secara berkelanjutan karena virus AI dapat menulari manusia (Horimoto, and Kawaoka., 2001; WHO, 2007).

\section{KESIMPULAN DAN SARAN}

Disimpulkan bahwa pengabdian masyarakat "Penyuluhan dan vaksinasi Flu Burung pada ayam buras di Desa Nyambu" sangat penting dilakukan sebagai upaya mencegah penyakit Flu Burung. Perlu dilakukan vaksinasi ulangan untuk meningkatkan titer antibodi ayam buras guna mencegah penyakit zoonosis Flu Burung di Bali agar KLB Flu Burung tidak terulang lagi.

\section{2 | BULETIN UDAYANA MENGABDI}




\section{UCAPAN TERIMAKASIH}

Penulis mengucapkan terimakasih kepada Lembaga Penelitian dan Pengabdian Kepada Masyarakat atas Universitas Udayana dengan Kontrak DIPA PNBP Universitas Udayana Tahun Anggaran 2018 Sesuai dengan Surat Perjanjian Penugasan Pelaksanaan Hibah Pengabdian kepada Masyarakat Udayana Mengabdi Pada Lembaga Penelitian dan Pengabdian Kepada Masyarakat Universitas Udayana Tahun 2018 Nomor: 384-26/UN14.4.A/PM/2018 tanggal 29 Maret 2018

\section{DAFTAR PUSTAKA}

Badan Pusat Statistik (BPS) Tabanan. 2017. Kecamatan Kediri dalam Angka 2017.

ISSN: 2477-7153. Badan Pusat Statistik Kabupaten Tabanan.

Daniels, P., A. Wiyono, E. Sawitri, B. Poermadjaja, and L.D Sims. 2013. H5N1 highly pathogenic avian influenza in Indonesia: retrospective considerations. Current Topics in Microbiology and Immunology. 365: 171-184.

Dudley., 2008. Insight, part of a Special Feature on Risk mapping for avian influenza: a social-ecological problem Public Health and Epidemiological Considerations For Avian Influenza Risk Mapping and Risk Assessment. Ecology and Society 13(2): http://www.ecologyandsociety.org/vol13/iss2/art21/ diakses 08 Pebruari 2018.

Jong MD., and Hien TT. 2006. Review Avian influenza A (H5N1). Journal of Clinical Virology 35: 2-13.

Horimoto, T and Y. Kawaoka. 2001. Pandemic threat posed by avian influenza A viruses. Clinical Microbiology Reviews. 14(1): 129-149.

Kencana,G.A.Y., Suartha, I.N., Simbolon, M.P.,Handayani, A.N., Ong, S., Syamsidar, Kusumastuti, A.2015.Respons Antibodi terhadap Penyakit Tetelo pada Ayam yang Divaksin Tetelo dan TeteloFlu Burung. Jurnal Veteriner. Vol. 16 No. 2 : 283-290.

Kencana, G. A. Y., Suartha, I. N., Paramita, N. M. A. S., Handayani, A. N. 2016. Vaksin Kombinasi Newcastle Disease dengan Avian Influenza Memicu Imunitas Protektif pada Ayam Petelur terhadap Penyakit Tetelo dan Flu Burung. Jurnal Veteriner 17 (2): 257 - 264.

Kencana, G. A. Y., Mahardika, I. G. N. K., Suardana, I. B. K., Astawa, I. N. M., Dewi, N. M. K., Putra, G. N. N. 2012. Pelacakan Kasus Flu Burung pada Ayam dengan Reverse Transkriptase Polymerase Chain Reaction. Jurnal Veteriner 13(3): 303-308.

Kencana GAY., Suartha, IN., Kardena IM. Avian Influenza Virus-H5N1 Is Circulating Among Backyard Chicken in MargaDistrict, Tabanan Regency, Bali. Proceeding of The $20^{\text {th }}$ FAVA Congress \& The $15^{\text {th }}$ KIVNAS PDHI, Bali Nov 1-3, 2018

Mahardika, I. G. N. K dan Tim Surveilans Pembebasan Penyakit AI FKH Unud. 2005. Laporan Surveilans Pembebasan Penyakit Avian Influenza di Propinsi Bali,Nusa Tenggara Barat dan Nusa Tenggara Timur. Fakultas Kedokteran Hewan Universitas Udayana: Denpasar. 
Mahardika, I. G. N. K dan Tim Surveilans Pembebasan Penyakit AI FKH Unud. 2006. Laporan Penelitian Kajian Epidemiologi Avian Influenza pada Babi dan Monyet serta Produksi Protein Rekombinan NS-1 untuk Pengembangan Reagensia Diagnostik DIVA. Fakultas Kedokteran Hewan Universitas Udayana: Denpasar

Mahardika, G.N., Adi, A.A.A.M,Besung, N.K.,Dharmawan, N.S.,Kencana, G.A.Y.,Rompis, A.L.T., Sampurna, P., LE Setiasih,L.E., Suardana, W., Suardana, I.B.K., GK Suarjana, G.K., Suartha, I N., Suartini, G.A.A., Suwiti N.K., and Utama, I.H. 2017. Surveillance of Avian Influenza Virus of H5N1 Subtype in Backyard Animals and Its Introduction in Bali, Indonesia. Pakistan Veterinary Journal . ISSN: 0253-8318 (PRINT), 2074-7764 (ONLINE). DOI: 10.229261/pakvetj/2018.002

WHO 2007. Review of latest available evidence on potential transmission of avian influenza (H5N1) through water and sewage and ways to reduce the risks to human health. Last updated 10/10/2007 